\title{
Correction to: Tregs and GvHD prevention by extracorporeal photopheresis: observations from a clinical trial
}

Roberto Crocchiolo ${ }^{*}$, Clara Cesana', Debora Girgenti', Giambattista Bertani², Claudia Barba' , Giuseppa Liga', Ursula Ferri ${ }^{1}$, Lara Crucitti ${ }^{2}$, Giovanni Grillo ${ }^{1}$, Silvano Rossini ${ }^{1}$ and Roberto Cairoli ${ }^{1}$

\section{Correction to: Exp Hematol Oncol (2021) 10:14} https://doi.org/10.1186/s40164-021-00210-9

Following publication of the original article [1], the authors reported error in author name. The authors first name and surnames are swapped in the submitted version and published.

The original article has been corrected.

\section{Author details}

${ }^{1}$ Servizio Di Immunoematologia E Medicina Trasfusionale, ASST Grande Ospedale Metropolitano Niguarda, Piazza Dell'Ospedale Maggiore, 3, 20162 Milano, Italy. ${ }^{2}$ ASST Grande Ospedale Metropolitano Niguarda, Milano, Italy.

Published online: 17 March 2021

\section{Reference}

1. Crocchiolo R, Cesana C, Girgenti D, Bertani G, Barba C, Liga G, Ferri U, Crucitti L, Grillo G, Rossini S, Cairoli R. Tregs and GvHD prevention by extracorporeal photopheresis: observations from a clinical trial. ExpHematol Oncol. 2021;10:14. https://doi.org/10.1186/s40164-021-00210-9.

\section{Publisher's Note}

Springer Nature remains neutral with regard to jurisdictional claims in published maps and institutional affiliations.

*Correspondence: roberto.crocchiolo@ospedaleniguarda.it

1 Servizio Di Immunoematologia E Medicina Trasfusionale, ASST Grande

Ospedale Metropolitano Niguarda, Piazza Dell'Ospedale Maggiore, 3,

20162 Milano, Italy

Full list of author information is available at the end of the article

(C) The Author(s) 2021. This article is licensed under a Creative Commons Attribution 4.0 International License, which permits use, sharing, adaptation, distribution and reproduction in any medium or format, as long as you give appropriate credit to the original author(s) and the source, provide a link to the Creative Commons licence, and indicate if changes were made. The images or other third party material in this article are included in the article's Creative Commons licence, unless indicated otherwise in a credit line to the material. If material is not included in the article's Creative Commons licence and your intended use is not permitted by statutory regulation or exceeds the permitted use, you will need to obtain permission directly from the copyright holder. To view a copy of this licence, visit http://creativecommons.org/licenses/by/4.0/. The Creative Commons Public Domain Dedication waiver (http://creativecommons.org/publicdomain/zero/1.0/) applies to the data made available in this article, unless otherwise stated in a credit line to the data. 